\title{
SEJARAH PERTUMBUHA DAN PERKEMBANGAN BAHASA ARAB
}

\author{
Latifah Salim
}

\author{
Universitas Islam Negeri (UIN) Alauddin Makassar
}

\begin{abstract}
Abstrak
Tulisan ini bertujuan untuk mendeskripsikan sejarah pertumbuhan dan perkembangan bahasa Arab yang dinilai sulit dilacak. Pengumpulan data dilakukan dengan menelusuri sumber bacaan terkait dan menganilisa sumber-sumber tersebut. Tulisan ini menemukan bahwa kesulitan dalam melacak sejarah pertumbuhan bahasa Arab karena bahasa ini merupakan bahasa yang sangat tua. Bahasa Arab adalah temuan dari prasasti tentang Arab Baidah yang diperkirakan hidup pada abad pertama sebelum masehi. Bahasa Arab adalah salah satu bahasa yang termasuk rumpun bahasabahasa Semit yang berdiam di sebelah selatan, tepatnya di wilayah Irak. Bahasa Semit sebagai bahasa induk utama dalam bahasa Arab membentuk bahasa-bahasa lain seperti Babilonia, Assiriyah, Ibrani, Aramiyah, Arab dan Etopiah. Perkembangan bahasa Arab meliputi zaman sesudah datangnya Islam, zaman Bani Umayyah, zaman Bani Abbasiah, zaman sesudah abad V H. dan perkembangan bahasa Arab di zaman modern.
\end{abstract}

Kata Kuci: Pertumbuhan, perkembangan, bahasa Arab, Semit.

\section{A. Pendahuluan}

Bahasa adalah realitas yang tumbuh dan berkembang sesuai dengan tumbuh kembangnya manusia pengguna bahasa itu.Realitas bahasa dalam kehidupan ini semakin menambah kuatnya eksistensi manusia sebagai mahluk berbudaya dan beragama. Kekuatan eksistensi manusia sebagai makhluk berbudaya dan beragama antara lain ditunjukkan oleh kemampuannya memproduksi karya-karya besar berupa sains, teknologi, dan seni yang tidak terlepas dari peran-peran bahasa yang digunakannya. Namun dalam konteks lain, bahasa bisa dijadikan alat propaganda, bahkan peperangan yang bisa membahayakan sesama jika pengguna bahasa tidak lagi melihat rambu- rambu agama dan kemanusiaan dalam penggunaannya. ${ }^{1}$

Bahasa pula dapat diartikan sebagai sistem suara yang terdiri atas simbol-simbol arbitrer (manasuka) yang digunakan oleh sesorang atau sekelompok orang untuk bertukar pikiran atau berbagi rasa, ${ }^{2}$ dan bahasa adalah sistem yang terbentuk oleh 2011), h.8.

${ }^{1}$ Acep Hermawan, MetodologiPembelajaran Bahasa Arab (Bandung: PT Remaja Rosdakarya,

${ }^{2}$ Muhammad ‘Ali al-Khu@li@, Asa@li@b Tadri@s al-Lugah al-'Arabiyyah (Riyadh : alMamlakah al-‘Arabiyyah al-Su’u@diyyah, 1982), h. 148. 
simbol-simbol, diusahakan, dan dapat berubah untuk mengekspresikan tujuan pribadi atau komunikasi antarindividu. ${ }^{3}$

Bahasa itu sebagaimana masyarakat pemakai bahasa tersebut, bahasa itu tumbuh, berkembang, dan akhirnya mati (punah). Syekh Ahmad al-Iskandari dan Mustafa Inany telah mengungkapkan hal tersebut bahwa bahasa 'Ad dan Samud dan lain sebagainya telah lenyap, berita mereka hanya dapat diketahui lewat pemberitaan al-Qur'an dan hadis Rasulullah saw. ${ }^{4}$

Bahasa Arab itu sendiri adalah salah satu bahasa Samiyah yakni bahasa Arab kuno, wilayah tempat tinggal mereka di Jazirah Arab. Bahasa Samiyah ini terdiri dari beberapa bahasa yang digunakan oleh anak-anak (keturunan) Sam bin Nuh, sedang bahasa Sam sendiri sudah tidak diketahui lagi.

Tulisan ini akan mendeskripsikan beberapa hal terkait asal usul bahasa Arab, pertumbuhan dan perkembangan, pembagian,dan menganalisis faktor yang melatarbelakangi kemenangan dialek Quraisy.

\section{B. Asal Usul Bahasa Arab}

Bahasa apa saja di dunia ini dapat dibagi kepada dua bahagian: Tipologi Genitis dan Tipologi Struktural. ${ }^{5}$ Sudaryanto menjelaskan lebih lanjut kedua pengertian di atas pertama adalah tipologi yang bersifat genitik ialah dasar yang mempertimbangkan hubungan kerabat bahasa yang akan diidentifikasikan coraknya. Hubungan itu tercermin dalam kemiripan-kemiripan yang tampak secara serempak

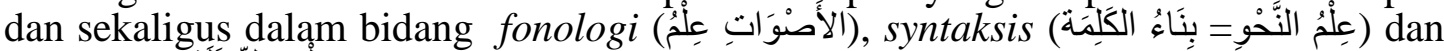
semantik (عَلُْ الدَّلَالَةِة) dari bahasa-bahasa yang bersangkutan. Dasar kedua adalah tipologi yang bersifat struktural ialah dasar yang mempertimbangkan kemiripan struktur dan sistem, tanpa memperdulikan kerabatnya. ${ }^{6}$

\section{Tipologi Genitis}

Menurut tipologi genitis ialah induk pembagian bahasa yang utama yaitu: Proto-Indo-Europen dan Chamito-Semitiques.

Sementara Max Muller dan Bunsen mengelompokkan bahasa menjadi 3 (tiga) rumpun yaitu: rumpun bahasa Indo-Eropa, dan rumpun bahasa Semit-Hamit dan rumpun bahasa Turania. ${ }^{8}$

Tipologi Chamito- Semitiques (Ham-Sam), maka bahasa-bahasa Semit dibagi kepada 2 (dua) bagian yaitu: bahasa-bahasa Semit Utara dan bahasa-bahasa Semit Selatan.

Penamaan bangsa Sam (al-Samiyun) diambil dari 3 (tiga) keturunan Nabi Nuh yang bernama Sam, Ham, dan Yapet. Akan tetapi dalam perkembangan keturunan ini hanya Sam ibn Nuh-lah yang telah mengadakan perjalanan panjang sehingga mendapat

${ }^{3}$ Ramzi Munir Ba'labaki, Mu’ja@mal-Musthalaha@t al-Lugawiyyah (Bairut: Dar al-'Ilm li al-Mala@yi@n, 1990), h. 272.

${ }^{4}$ Ahmad Iskandar dan Mustafa Inany, Al-Wasit fi al-Adab al-Arabi wa Tari>kuhu>, (Mesir: Dar al-Ma'a>rif, t.th),h.5

${ }^{5}$ Yayasan Kanisius., Teori Linguistik dan Bahasa Indonesia, (Yogyakarta, t.p, 1980), h. 32.

${ }^{6}$ Sudaryanto., Predikat-Obyek dalam Bahasa Indonesia, (Jakarta: Djambatan, 1983), h. 22.

${ }^{7}$ Crystal., Linguistics, (England, Middlessex, t.th), h. 150.

${ }^{8}$ Mulyanto Sumardi, et.al., Pedoman Pengajaran Bahasa Arab pada Perguruan Tinggi Agama Islam IAIN, (Jakarta: Proyek Pengembangan Sistim Pendidikan RI, 1976), h. 29. 
kekuasaan dan juga perluasan wilayah yang pada akhirnya membentuk dan melahirkan berbagai bangsa dan bahasa, di antaranya adalah bangsa Akkadia, Kan'an, Arab, Aram dan Etopia.

Bahasa ditinjau dari segi genitisnya bahasa Arab termasuk rumpun bahasa Semit, dan dilihat dari segi geografisnya terbagi atas 2 (dua) bagian yaitu bahasabahasa timur dan barat. Bahasa-bahasa timur ini terdiri atas Babil dan Assur yang sering disebut Akkadia. Sedangkan bahasa-bahasa barat terbagi kepada utara dan selatan, sedangkan bahasa utara terbagi atas dua bahasa besar, yaitu Kan'an dan Aramin. Yang termasuk bahasa Kan'an adalah bahasa Kan'an Kuno, Muab, Finiq, dan Ibriah. Sedang bagian selatan yang dibagi lagi menjadi 2 (dua) bahasa besar yaitu Arab selatan dan Arab utara. Adapun yang termasuk bahasa Arab selatan yaitu: dialek Main, Saba', Himyar Quataban, dan Hadramaut, sedang bahasa Arab utara terbagi kepada bahasa Arab Baidah yang terdiri dari Lahyan, Samud, dan Shafa, sedang bahasa Arab Baqiyah terbagi kepada 2 (dua) bagian yaitu: Arab Aribah yang terdiri dari Kahlan dan Himyar, dan Arab Musta'ribah, dari Musta'ribah turun ke Bani Adnan, kemudian ke Bani Kinanah dan baru sampai kepada suku Bani Quraisy.

\section{Tipologi Struktural}

Jika dilihat strukturnya, maka bahasa-bahasa di dunia dapat digolongkan kepada 3 (tiga) pembagian. Pembagian tipologi ini dipelopori oleh A. Von Schlegel tahun 1818. ${ }^{10}$ Walaupun bahasa-bahasa itu tidak satu rumpun, atau berjauhan letaknya, mungkin saja dapat digolongkan kepada satu tipologi tersebut.

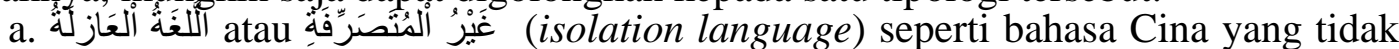
mempunyai inflection, bahasa yang tidak berkonjugasi. Bentuk katanya tidak berubah-ubah.

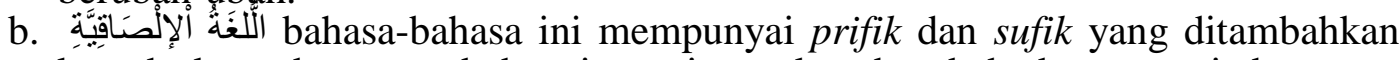
kepada kata dasar, tambahan itu artinya akan berubah dengan arti dasarnya, seperti bahasa Indonesia, Jepang dan Turki.

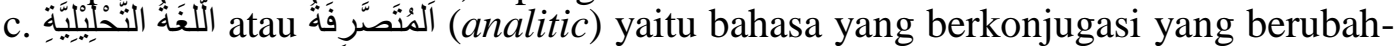
ubah bentuk kata dasarnya dengan adanya perubahan arti pula seperti bahasa Arab.

\section{Pertumbuhan dan Perkembangan Bahasa Arab}

\section{Pertumbuhan Bahasa Arab}

Sebagaimana dijelaskan sebelumnya, bahwa bahasa Arab adalah salah satu bahasa yang termasuk rumpun bahasa-bahasa Semit yang berdiam di sebelah selatan, tepatnya di wilayah Irak. ${ }^{11}$ Dengan demikian, hubungan antara bahasa Arab dengan Semit sangat kuat.

Menurut Abdul Wahid Wa'fiy, informasi yang sempat terekam dalam sejarah yang sampai kepada kita tentang sejarah bahasa Arab adalah temuan dari prasasti

${ }^{9}$ Khatibul Umam, et. al., Pedoman Pengajaran Bahasa Arab pada Perguruan Tinggi IAIN, (Jakarta: Proyek Pengembangan Sistem Pendidikan Agama RI, 1975), h. 47. Lihat pula Bambang Yudi., Kristal-kristal Ilmu Bahasa, (Cet. I; Surabaya: Airlangga University Press, 1995), h. 379.

${ }^{10}$ Crystal, Linguistics , h. 152. Lihat pula Subhi al- Shaleh, Dirâsat fî Fikh al- Lughah, (Cet II; Beirut: Mansyurat al- Maktabah al- Ahliyah, 1962), h. 34.

${ }^{11}$ Lihat Abdul Wahid Wa'fi, 'Ilmu al- lughah (Cet. V; Misr: Maktabah Nahdhah Misr, 1962), $10-11$. 
tentang Arab Baidah yang diperkirakan hidup pada abad pertama sebelum masehi, sedangkan Arab Baqiyah nanti setelah abad kelima masehi, sehingga priodisasi pertumbuhan bahasa Arab sangat sulit untuk dilacak. ${ }^{12}$

Hal yang senada dikemukakan oleh Anwar G. Chejne bahwa data bahasa Arab secara tertulis masih sangat sedikit jika dibanding dengan bahasa-bahasa lain, sehingga priodisasi bahasa Arab dan kesusastraannya hanya terbatas pada masa Jahiliyah, masa munculnya Islam, yang dibawa oleh Nabi Muhammad saw. Masa Bani Umaiyyah, dan masa Bani Abbasiah, masa kemunduran dan masa modern. ${ }^{13}$ Berkaitan dengan priodisasi tersebut di atas, bahwa yang diperpegangi oleh para ahli tentang pertumbuhan bahasa Arab, yaitu sejak pra Islam (Jahiliyah) ${ }^{14}$ yang mana pada saat itu sudah ada karya-karya sastra Arab baik syair ataupun pidato yang tidak menonjolkan dialek-dialek tertentu, menggunakan bahasa yang mudah dipahami. Dengan jalan ini, kemudian terbentuklah suatu bahasa Arab kesusastraan, yang menjadi bahasa baku (standar) yang dipergunakan oleh setiap penyair dalam menyampaikan ide-idenya.

Dari uraian di atas, jelaslah bahwa menjelang datangnya Islam telah lahir bahasa Arab

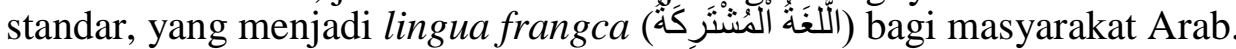

\section{Perkembangan Bahasa Arab.}

\section{a. Zaman sesudah datangnya Islam}

Dengan datangnya Islam dan turunnya al-Qur'an dalam bahasa Arab standar, kedudukan bahasa Arab standar menjadi lebih penting dan menarik perhatian kalangan masyarakat yang lebih luas. Semakin besar jumlah pemeluk Islam, semakin meluas pengaruh bahasa Arab standar ini sampai pada kehidupan kalangan orangorang awam. Karena didorong oleh jiwa dan semangat keagamaan, pemeluk agama Islam mempunyai kecintaan membaca al-Qur'an, baik untuk ta'abud (ibadah) dengan tilawah (bacaan) al-Qur'an itu semata ataupun lebih lanjut untuk memahami isi alQur'an dan menggali ajaran-ajaran Islam.

Dari sinilah mulai terbina hubungan yang menjalin bahasa Arab dengan agama Islam, sehingga membawa akibat yang jauh sekali bagi masa depan bahasa Arab yang kemudian menjadi bahasa agama dan kebudayaan bagi dunia Islam.

\section{b. Perkembangan bahasa Arab di Zaman Bani Umayyah.}

Di zaman pemerintahan Bani Umayyah terjadi perubahan sosial dalam masyarakat Islam. Orang-orang Arab mulai berasimilasi dengan penduduk asli, karena kelompokkelompok sosial itu makin hari makin bercampur. Untuk memenuhi kebutuhankebutuhan hidup mereka, tentara Islam dan pendatang-pendatang baru (Arab) itu tidak dapat menghindar hubungan dengan penduduk asli. Penduduk asli inipun berkepentingan mempelajari bahasa Arab untuk dapat saling mengerti dalam berkomunikasi dengan orang-orang Arab tersebut, maka lahirlah suatu dialek khusus yang mereka pergunakan sehari-hari.

\section{${ }^{12}$ Abdul Wahid Wa'fi, 'Ilmu al- lughah, h. 97.}

${ }^{13}$ Lihat Mulyanto Sumardi., h. 34. Lihat pula Karl Brokleman, Târikh al-Adab al- 'Araby, Jilid I, (Cet. IV; al- Qahirah: Dar al- Ma'rif, t.th), h. 36-38.

${ }^{14}$ Lihat Muhammad Suyuti Suhaib., Kajian Puisi Arab Pra Islam, (Cet. I; Jakarta: al- Quswa, 1990), h. 1-2. 
Berbicara tentang bahasa Arab yang fashih (bahasa Arab standar), menunjukkan ketinggian martabat sosial dan sebaliknya menggunakan bahasa atau dialek-dialek lain itu menandakan kerendahan tingkat sosial mereka.

Dalam konteks kehidupan sosial seperti itu tidak mengherankan kalau para pejabat dan pemimpin masyarakat sangat berkeinginan mendidik putera-putera mereka dalam lingkungan Arab Badui, dengan maksud agar dikemudian hari memiliki kelebihan dan keistimewaan atas masyarakat kelas rendah, dengan demikian mudah tergolong orang-orang yang berkelayakan untuk memangku jabatan pemerintahan, sehingga mereka mengirim putera-putera mereka ke pelosok desa untuk belajar bahasa Arab pada orang-orang Badui.

Faktor lain pula yang perlu diketahui bahwa akhir abad pertama Hijriyah di mana bahasa Arab telah mencapai posisi tinggi, terhormat dan kuat dalam wilayah negara Islam disebabkan:

a. Setelah "pengaraban" (Arabisasi) administrasi pemerintahan di mulai sejak kira-kira tahun $87 \mathrm{H}$, bahasa Arab dengan sendirinya telah menjadi bahasa resmi negara Islam.

b. Bahasa Arab adalah bahasa masyarakat kelas tinggi, yang dipergunakan para pejabat dan petugas pemerintahan yaitu penggunaan bahasa Arab fashih.

c. Bahasa Arab yang fashih tetap menjadi bahasa sya'ir (puisi), sedang sya'ir bagi masyarakat kelas tinggi menjadi kebanggaan.

d. Bahasa Arab adalah bahasa al-Qur'an, bahasa yang dipergunakan dalam ibadah, oleh karena itu umat Islam berkepentingan mempelajarinya.

\section{c. Perkembangan bahasa Arab di zaman Bani Abbasiah.}

Pemerintahan Arab (Bani Umaiyyah) jatuh, tetapi bahasa Arab tidak ikut jatuh. Bahasa Arab tetap menempati posisi yang tinggi dan berperanan seperti semula, meskipun zaman bani Abbas menurut ahli-ahli sejarah merupakan kemenangan bagi orang-orang Persia terhadap orang-orang Arab Bani Umaiyyah.

Bani Abbas sejak semula memang mengetahui dan berkeyakinan bahwa pengaruh dan kekuasaaan mereka tergantung pada perkembangan dan kemajuan agama Islam, karena pemerintahan mereka ini ditegakkan di atas landasan agama. Kitab suci dan mu'jizat terbesar agama Islam adalah al-Qur'an, sedang al-Qur'an itu berbahasa Arab. Karena itu dalam pandangan dan perasaan setiap muslim apapun bahasa aslinya bahasa Arab sebagai bahasa al-Qur'an adalah bagian yang tidak terpisahkan dari hakekat Islam.

Inilah sebabnya, maka dalam alam pemerintahan Bani Abbas, bahasa Arab memperoleh perhatian serius dan usaha-usaha pemeliharaan serta pengembangan sebaik-baiknya.

Kalau Bani Umayyah mempunyai pertalian dengan masyarakat Badui, seperti dijelaskan di atas, untuk menguasai bahasa Arab yang baik dan benar putera-putera mereka dikirim ketengah-tengah masyarakat Badui, yang masih terisolir dari percampuran dengan orang-orang 'ajam (non-Arab).

Bani Abbas tetap yakin bahwa pentingnya menguasai bahasa Arab bagi putera-putera mereka. Namun karena dalam hal orientasi berfikir maupun secara perasaan tidak bersangkut-paut dengan masyarakat Badui, Bani Abbas tidaklah mengirim puteraputera mereka ke masyarakat Badui. Karena itu pada abad II H, orang-orang Baduilah yang didatangkan ke Baghdad dan muncul istana-istana para penguasa sebagai guruguru bahasa Arab.

Satu hal yang perlu diingat bahwa karena terjadinya asimilasi Arab dan non-Arab,

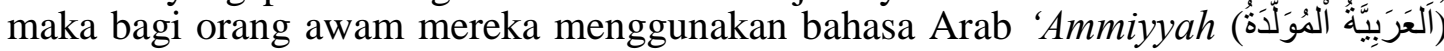


atau bahasa Arab campuran kemudian menjadi bahasa percakapan dan alat komunikasi di antara mereka.

Pada abad III H pengaruh bahasa Arab 'amiyyah nampak lebih jelas pada kelompok awam, bahkan sudah mulai terdapat buku-buku ilmiyah ditulis dengan bahasa yang kurang murni, karena mengandung gaya bahasa dan kata-kata bahasa Arab Muwalladah. Jadi, pada pertengahan abad III H, bahasa percakapan mengalami kemunduran yang menyedihkan, banyak para pejabat yang berbicara dengan menggunakan bahasa 'amiyyah, akibat unsur non-Arab semakin banyak menduduki jabatan penting dan semakin jauh mencampuri masalah-masalah politik dan pemerintahan. Bahkan para ahli nahwu pun pada akhir abad ini menggunakan bahasa 'amiyyah dalam bahasa percakapan mereka sehari-hari.

Peristiwa ini muncullah pemikiran baru untuk mengoreksi penggunaan yang salah dalam bahasa percakapan dengan menggunakan bahasa 'amiyyah, maka para pemerhati menulis kritikan-kritikan dan menuangkan tulisan-tulisannya dalam bentuk buku-buku tentang penggunaan bahasa Arab fushah di kalangan masyarakat.

Kehadiran buku-buku tersebut mencerminkan suatu langkah maju bagi orang yang ingin mempelajari bahasa Arab, maka pada abad IV H. dapat dikatakan hampir tidak ada lagi orang mempelajari bahasa Arab dengan mendatangkan dan menerima langsung dari orang-orang Badui. Bahasa Arab dipelajari melalui buku-buku pelajaran mulai saat itu banyak tersebar dimana-mana.

\section{d. Perkembangan bahasa Arab sesudah Abad V H.}

Sesudah dunia Arab terpecah-belah dan diperintah oleh penguasa-penguasa politik non-Arab, bahasa Arab tidak lagi menjadi bahasa politik dan bahasa administrasi dalam pemerintahan. Bahasa Arab tersudut menjadi bahasa hanya semata-mata bahasa agama.

Sejak itu orang-orang Saljuk yang berkuasa pada abad V H. bahasa Persia diumumkan sebagai bahasa resmi negara yang mereka pimpin. Sejak itu orang-orang Persia (Iran) mulai mengarang dengan bahasa Persia. Sebahagian orang mulai meninggalkan penggunaan bahasa Arab.

Pada tahun $459 \mathrm{H}$ dibangunlah sebuah lembaga pendidikan yang menangani pengajaran bahasa Arab yakni madrasah An-Nidhamiyyah. Dibangunnya madrasah ini menunjukkan perhatian kaum Saljuk terhadap bahasa Arab fushah meskipun untuk kehidupan sosial politik bahasa Persia dianggap penting. Mereka berpendapat bahwa bahasa Arab adalah kunci untuk memperdalam pengetahuan agama Islam dari alQur'an dan as-Sunnah.

Pada abad VI H ini ada perkembangan baru yang perlu dicatat, yaitu munculnya "lahn" atau kekeliruan dalam berbahasa dan membaca al-Qur'an, dan ini sudah menjadi kebiasaan di kalangan masyarakat termasuk di kalangan masyarakat terpelajar, padahal pada abad II H yang membuat kesalahan dalam berbahasa adalah orang awam.

\section{e. Bahasa Arab di Zaman Modern.}

Seperti diketahui, karena situasi umum yang stasis selama pemerintahan Usmaniyah, maka bahasa Arab dalam periode itu juga mengalami keadaan statis, tidak berkembang mengikuti kemajuan hidup modern yang di bawa oleh zaman sesudah terjadinya kebangkitan di Eropa.

Sesudah kekuasaan politik Perancis mulai menjajah Mesir akibat dari berhasilnya serbuan Napoleon (tahun 1798 M), di Mesir mulailah berkembang keadaan untuk bangkit dan maju dengan landasan ilmu pengetahuan modern. Kesadaran tersebut 
lahir di kalangan sekelompok masyarakat di Mesir setelah mereka terpengaruh oleh golongan intelektual Eropa yang datang ke Mesir bersama serbuan Napoleon.

Golongan intelektual Eropa tersebut di Mesir membangun pelbagai sarana yang melandasi dan mendorong perkembangan ilmu pengetahuan di Mesir seperti: lembaga ilmu pengetahuan, perpustakaan, sekolah, surat kabar, laboratorium penelitian, percetakaan Arab dan lain sebagainya.

Sekolah-sekolah dibuka untuk mempelajari macam-macam ilmu pengetahuan seperti pengetahuan kemiliteran, kedokteran, kedokteran hewan, tehnik, pertanian, kesenian, administrasi, bahasa dan terjemah dan lain-lain. Bahasa Arab adalah bahasa pengantar pada sekolah-sekolah tersebut, karena guru-guru yang mengajar pada umumnya adalah sebagian besar alumni Eropa dari group missi mahasiswa Mesir yang beberapa tahun sebelumnya telah berhasil melanjutkan studi di Eropa. Kuliahkuliah yang diberikan oleh guru-guru besar asing juga disampaikan dalam bahasa Arab setelah melalui penerjemahan.

Inilah salah satu langkah yang berhasil dalam rangka usaha mengatasi ketebelakangan bahasa Arab, dan sekaligus meletakkan dasar kokoh bagi bahasa Arab untuk menjadi bahasa yang dinamis dan mampu berkembang secara wajar.

Periode Modern (1800-dan seterusnya), merupakan zaman kebangkitan umat Islam. Jatuhnya Mesir ke tangan Barat menginsafkan dunia Islam akan kelemahannya dan menyadarkan umat Islam bahwa di Barat telah timbul peradaban baru yang lebih tinggi dan merupakan ancaman bagi Islam. Raja-raja dan pemuka-pemuka Islam mulai memikirkan bagaimana meningkatkan mutu dan kekuaatan umat Islam kembali. Periode Modern inilah timbulnya ide-ide pembaharuan dalam Islam.

\section{Pembagian Bahasa Arab}

Dalam pembagian bahasa Arab terbagi 2 (dua) kelompok besar yaitu; Arab Baidah dan Arab Baqiyah.

\section{Bahasa Arab Baidah.}

Bahasa Arab Baidah disebut pula bahasa Arab al-Nuqusy, karena informasi tentang bahasa ini hanya diperoleh melalui tulisan pada lempengan batu, dan bahasa Arab Baidah ini sudah punah ditelan masa. Bahasa Arab Baidah ini dituturkan oleh orang Arab yang berdomisili di sebelah utara Hijaz atau berdekatan bangsa Aramiah. Bahasa Arab Baidah ini terbagi atas 3 (tiga) bagian; Lihyan, Samud, dan Shafa.

a. Lihyaniayah, dinisbahkan dari nama kabilah atau suku yang bernama lihyan yang tinggal di bagian utara Hijaz. Sayang informasi akurat tentang kabilah ini belum ditemukan.

b. Samudiah, dinisbahkan kepada suku Samud sebagaimana yang dikisahkan dalam al-Qur'an dan direkam pula dalam kitab perjanjian lama baik Yunani maupun Roma, dan masyhur disebut di dalam sejarah jahili. Suku ini diperkirakan mendiami wilayah antara Hijaz dan Nejed dekat Damaskus. Bahasa Samud ini diperkirakan pada abad ke 3 dan $4 \mathrm{M}$.

c. Safawiyah, adapun informasi tentang suku ini diperoleh melalui prasasti yang penulisannya diperkirakan antara abad ketiga dan keenam masehi.

Demikianlah ketiga dialek tersebut yang termasuk bagian dari bahasa Arab Baidah.

\footnotetext{
${ }^{15}$ Abdul Wahid Wa'fi., 'Ilmu al- lughah, h. 98-101.
} 


\section{Bahasa Arab Baqiyah.}

Yang dimaksud dengan bahasa Arab Baqiyah ialah bahasa yang masih dipergunakan oleh bangsa Arab baik dalam tulisan, kesusastraan dan sebagainya. Bahasa ini tumbuh dan berkembang di negeri Nejed, dan Hijaz. Kemudian tersebar luas ke sebagian besar negeri Semit dan Hamit. ${ }^{16}$ Dari sini timbul dialek-dialek yang dipergunakan di masa kini seperti, Hijaz, Nejd, Yaman, dan daerah sekitarnya seperti Emirat Arab, Palestina, Yordan, Syria, Libanon, Irak, Kuwait, Mesir, Sudan, Libia, al-Jazair dan Maroko.

Bahasa Arab Baqiyah terbagi kepada dua bagian, ${ }^{17}$

a. Arab al-Aribah, mereka yang berasal dari Qahtan. Bani Qahtan dengan dua suku induknya, Kahlan dan Himyar, mendirikan Himyar dan Tababi'at. Disebut dalam al-Qur'an "Tabba". Selain itu mereka pula mendirikan kerajaan Saba' kira-kira abad ke-8 SM. Bani Qahtan inilah yang memerintah semenanjung Arabiyah sesudah al-Arab al-Baidah.

b. Arab al-Musta'ribah, keturunan Nabi Ismail, mereka kemudian terkenal dengan nama "bani Adnan", suku inilah yang merebut kekuasaan bani Qahtan. Bani Adnan tinggal di Hijaz, Nejed dan Tihamah. Bani Adnan mempunyai empat suku induk yaitu Rabi'ah, Mudhar, Iyad, dan Anmar.

Dari kabilah ini lahirlah beberapa kabilah, di antaranya Bani Kinanah yang selanjutnya melahirkan kabilah Quraisy.

Setelah seluruh semenajung Arabiah telah tunduk ke bawah kekuasaan Islam, barulah pasukan Islam itu mencoba melakukan ekspansi ke daerah-daerah di luar dan dimulai pada zaman khalifah pertama Abu Bakar al-Siddiq, kemudian diteruskan oleh khalifah berikutnya. Mereka menaklukkan Syria, Irak, Mesir, Sudan, Maroko, Damaskus, dan Palestina, semenjak itu bahasa Arab menjadi bahasa resmi daerah itu.

Tersebarnya bahasa Arab Baqiyah tidak lepas dari pengaruh dan peran Islam pada saat itu yang melakukan perluasan wilayah. Tunduknya wilayah tersebut memungkinkan bahasa Arab Baqiyah dipelajari, apalagi sumber ajaran Islam yang pertama dan utama adalah al-Qur'an yang ditulis dalam bahasa Arab, andaikata bukan karena al-Qur'an kemungkinan besar bahasa Arab punah pula seperti halnya bahasa Semit lainnya. Itulah sebabnya bahasa Arab Baqiyah bertahan dan tidak lenyap selama al-Qur'an masih saja ada dipermukaan bumi ini.

Melacak historis bahasa Arab Baqiyah kapan munculnya tidak diketahui secara pasti karena data yang menjelaskan hal itu baik tulisan prasasti ataupun bentuk lain tidak ada.

Peninggalan yang menjelaskan keberadaan bahasa Arab Baqiyah ialah adab Jahiliyah. Adab Jahiliyah ini berupa peninggalan sastra yang berasal dari sekelompok penyair-penyair masa jahiliyah beserta para cendekiawan (hukama') dan oratororatornya. Tetapi peninggalan itu tidak dikumpulkan dan ditulis kecuali pada abadabad pertama masa Islam. Menurut para ahli, bahasa Arab tumbuh dan berkembang pada abad ke 5 M. ${ }^{18}$

${ }^{16}$ Abdul Wahid Wa'fi., 'Ilmu al- lughah, h. 98-101.

${ }^{17}$ Mustafa Inaniy, al- Wasîth Fî al-Adab al- 'Araby Wa Târikhuhu, (Mesir: Dâr al- Ma'rif, t.th). h. 5-6

${ }^{18}$ Abdul Wahid Wa'fi., 'Ilmu al- lughah, h. 103-104. 
Setelah kedatangan Islam, bahasa Arab berkembang dan baru mengalami kemunduran setelah jatuhnya kota Baghdad pada tahun $1258 \mathrm{M} .{ }^{19}$ Kemudian Bahasa Arab berkembang lagi pada masa kejayaan bangsa Turki sampai datangnya masa Arab modern pada abad ke $19 \mathrm{M}$.

\section{E. Kemenangan Dialek Quraisy}

George Zaidan ${ }^{20}$ membagi sastra Jahiliy menjadi 2 bagian; pertama sebelum abad ke-5 M, dan kedua masa dari abad ke-5 M, sampai dengan kedatangan Islam (permulaan abad ke-7 M), bahasa yang tumbuh sejak abad ke-5 $\mathrm{M}$ itulah yang berkembang mencapai puncaknya di masa kedatangan Islam, yaitu dialek Quraisy ( Dialek Hijaz) mengalahkan dialek Tamim ( dialek Nejd). Dengan kemenangan dialek Quraisy tersebut praktis bahasa Quraisylah yang dipergunakan oleh semua suku Arab dalam semua lapangan baik dalam bidang sastra, apakah dalam bentuk prosa dan puisinya maupun dalam pidato. Kemenangan dialek Quraisy ( dialek Hijaz) terhadap dialek Tamim ( dialek Nejed).

Adapun faktor-faktor yang membantu kemengan dialek Quraisy, antara lain;

\section{Faktor Agama}

Quraisy sebuah nama suku yang terkemuka di antara suku-suku lain di Mekah, suku penyelenggara pemerintahan di Mekah sebelum datangnya Islam, tempat bertumpu semua kabilah dari seluruh tanah Arab. Kedudukannya sebagai penyelenggara pemerintahan di Mekah dan sekaligus pelayan Ka'bah, sudah sering menjadi sumber perselisihan dan kadang-kadang bersifat fisik. Kabilah-kabilah yang merasa kuat saling berebut kekuasaan untuk menjadi pelayan Ka'bah. Hal ini wajar saja sebab selain Ka'bah sangat dihormati oleh sekalian suku-suku disekitar Mekah, di sana terdapat juga sumur zam-zam, sumber air yang tiada kering-keringnya, di samping Mekah sebagai tempat transit para kabilah yang berniaga dan mengambil route dari Yaman di selatan, ke Syam di Utara.

Keberhasilan suku Quraisy di Mekah banyak dibantu oleh kemampuan seorang pemuka Quraisy bernama Qushai Ibn Kilab dengan menggantikan Khuza'ah dalam pertarungan masalah Ka'bah. Dengan kemenangan inni reputasi dan gengsi Quraisy kembali Nampak.

Menurut pandangan kebanyakan suku-suku di masa Jahiliyah menganggap bahwa rumah Allah merupakan tempat suci bagi mereka. Oleh sebab itu, mereka menunaikan manasik haji di sana. Mereka mengunjungi patung-patung sekaligus menyuguhkan kurban-kurban untuk mendekatkan diri kepada pencipta. Dalam segala urusan Quraisylah yang memegang kekuasaan agama di antara suku-suku Arab lainnya.

\section{Faktor Ekonomi}

Di samping faktor agama, suku Quraisy pula menguasai dan mengendalikan perdagangan ekonomi.

Ada beberapa faktor yang menyebabkan suku Quraisy memegang peranan dalam perniagaan di kota Mekah waktu itu, terutama orang-orang Yaman yang telah berpindah ke Mekah ( setelah dijajah oleh bangsa Habsyi dan bangsa Persia pada kerajaan Saba' dan Himyar), sedang mereka mempunyai pengalaman yang luas dalam pernniagaan. Dalam kurung waktu itu, kota Mekah dari hari kehari bertambah

\footnotetext{
${ }^{19}$ Harun Nasution., Islam Ditinjau Dari Berbagai Aspeknya, Jilid I, (Jakarta: UI.-Press, 1985), h. 81 .

${ }^{20}$ Zaidan, Tarikh Adab al-Lughah al-Arabiyyah, jilid 4 (Cairo, MEsir: Dar al-Hilal, t.th
} 
masyhur sesudah Ka'bah didirikan, dan jama'ah- jama'ah haji pun berdatangan dari segenap penjuru Jazirah Arab tiap tahun. Keadaan itu menyebabkan Quraisy amat dihormati oleh bangsa Arab lainnya, apalagi penghargaan dan pelayanan Quraisy terhadap jama'ah haji itu amat baik.

Faktor lain, ialah letak geografis kota Mekah itu sendiri sangat strategis karena berada di tengah-tengah antara utara dan selatan. Di samping itu keadaan buminya yang kering dan tandus, menyebabkan penduduknya suka merantau untuk berniaga, sebagai suatu usaha yang utama, dan sumber yang terpenting bagi penghidupan mereka.

Dengan demikian perniagaan suku Quraisy menjadi giat, serta mendapat kemasyhuran dan kemajuan yang besar di dalam dan di luar Jazirah Arab. Mereka itu berpindah-pindah dari satu tempat ke tempat yang lain dengan membawa barang dagangannya di berbagai tempat di Jazirah Arab, dari Syria sebelah utara sampai ke negeri Yaman di Selatan.

Orang Quraisy biasa mengadakan perjalanan dan perdagangan secara teratur seagaimana yang digambarkan dalam al-Qur'an, QS: al-Quraisy (106);1-4

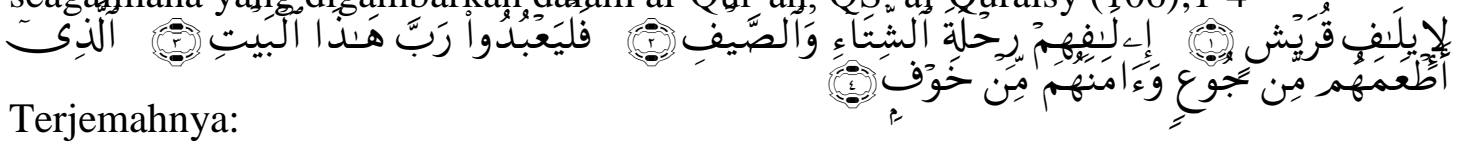

Karena kebiasaan orang-orang Quraisy, (yaitu) kebiasaan mereka bepergian pada musim dingin dan musim panas, Maka hendaklah mereka menyembah Tuhan Pemilik rumah ini (Ka'bah)., Yang telah memberi makanan kepada mereka untuk menghilangkan lapar dan mengamankan mereka dari ketakutan.

Berkat kegiatan perdagangan ini, membuat orang-orang kaya berada pada suku Quraisy.

\section{Faktor Politik}

Adanya dua faktor tersebut diatas, (agama dan ekonomi) di samping letak geografisnya yang strategis, menyebabkan terealisasinya pengaruh politik yang kuat diseluruh negeri Arab pada zaman jahiliyah. Dalam hal ini, Abu Bakar al-Shiddiq ra. Dalam jawabannya kepada kaum Anshar yang ingin memegang tampuk pemerintahan setelah wafatnya Rasulullah saw. Ia berkata orang Arab tidak akan beragama kecuali karena adanya pusat kegiatan politik di tangan Quraisy, sebab itu janganlah saingi saudara-saudaramu itu dengan kelebihan yang telah diberikan Allah kepada mereka.

\section{Faktor Musyawarah}

Praktek musyawarah antara suatu kabilah tampaknya telah dikenal sejak masa pra-kenabian (masa jahiliah). Praktek semacam ini Nampak pula pada kebiasaan orang-orang Arab, dimana mereka sering mengadakan perkumpulan untuk bertukar pikiran, bermusyawarah dalam berbagai hal baik menyangkut urusan kemasyarakatan ataupun urusan pemerintahan. Mereka juga sering berkumpul sekedar untuk bersenang-senang dan menceritakan sejarah masa lalu mereka dan saling tukar menukar pengalaman. Jadi bangsa Arab Quraisy menempatkan musyawarah sebagai wahana pengambilan keputusan di kalangan pemuka kabilah. Praktek musyawarah di kalangan kaum Quraisy cukup banyak, antara lain sewaktu Qushai Ibn Kilab bapak kelima dari Muhammad saw., bangkit dan mempersatukan bangsa Quraisy sehingga mampu menandingi dan mengalahkan kaum Khuza'ah. Akhirnya dia dapat menguasai Ka'bah dan diangkatlah sebagai kepala di Negeri Mekah, kepala agama dan penguasa tertinggi.

Contoh lain yang cukup dikenal dalam sejarah adalah peristiwa penempatan kemabali Hajar Aswad yang mengantar Muhammad saw. mendapat julukan al-Amin. 
Praktek ini berlangsung terus setelah Muhammad memperoleh legitimasi kenabian sejak periode Mekah, bahkan musyawarah juga tetap berlangsung di kalangan kafir Quraisy, seperti ketika mereka berusaha untuk menangkal dan menghalangi gerakan dakwah Rasulullah saw. Musyawarah yang melibatkan pihak-pihak Quraisy dan Muhammad beserta para pengikutnya lebih dikenal dengan perjanjian damai.

Menjelang umat Muhammad memperoleh perintah berhijrah ke Madinah, Rasulullah telah membuat perjanjian persaudaraan seiman dengan kaum Yatsrib ( dari kabilah Auz dan Khazraj) menerima kehadiran umat Muhammad dan untuk saling memberikan perlindungan. Puncak dari proses ini adalah terbentuknya masyrakat baru umat Islam dan sebuah piagam Madinah.

Musyawarah terbesar sepanjang sejarah di awal perkembangan Islam adalah terbuka dihadapan publik umat Islam pasca wafatnya Rasulullah saw.

Kondisi-kondisi seperti apa yang dikemukakan di atas dalam rangka melaksanakan musyawarah dan pertemuan, mereka menggunakan bahasa dialek Quraisy sebagai bahasa pengantar di antara kabilah-kabilah tersebut.

\section{Faktor Pasar}

Orang-orang Arab memiliki pecan-pekan umum untuk mempromosikan barang dagangannya, karya sastra dan lain sebagainya. Sebelum datangnya Islam sudah menjadi adat kebiasaan bagi bangsa Arab Jahiliyah untuk mengadakan munazarah mendengarkan para penyair membacakan syair-syairnya.

Ada beberapa pecan tempat dimana para penyair itu berkumpul, yaitu: pasar Ukkaz, Zul Majas, dan Zul Majannah. ${ }^{21}$ Ketiga pasar itu orang-orang Arab banyak mendapat manfaat, disana mereka berlomba memperhalus bahasa mereka, baik dari segi pidato, puisi, dan prosa, disana pula mereka saling menukar tawanan mereka, mendamaikan permusuhan, mereka saling mendambakan keturunan mereka, saling mengutarakan kemuliaan yang dikerjakan oleh nenek moyang mereka, saling mengemukakakan kelebihan dan mereka bersenandung dengan cinta kasih dan keindahan. Perlombaan bahasa yang bagus lebih diutamakan daripada perdagangan harta benda. Semua yang dikatakan pada pasar-pasar tersebut disusun dalam bahasa yang digunakan oleh bahasa Arab dalam bidang sastra yaitu dialek Quraisy. Hal ini pulalah yang meninggalkan kesan adan bekas yang mendalam dalam kebangkitan dialek Quraisy.

${ }^{21}$ Ahmad Iskandar dan Mustafa Inany, Al-Wasit fi al-Adab al-Arabi wa Tari>kuhu>, h. 12 


\section{Bagan Asal Usul Bahasa Arab}
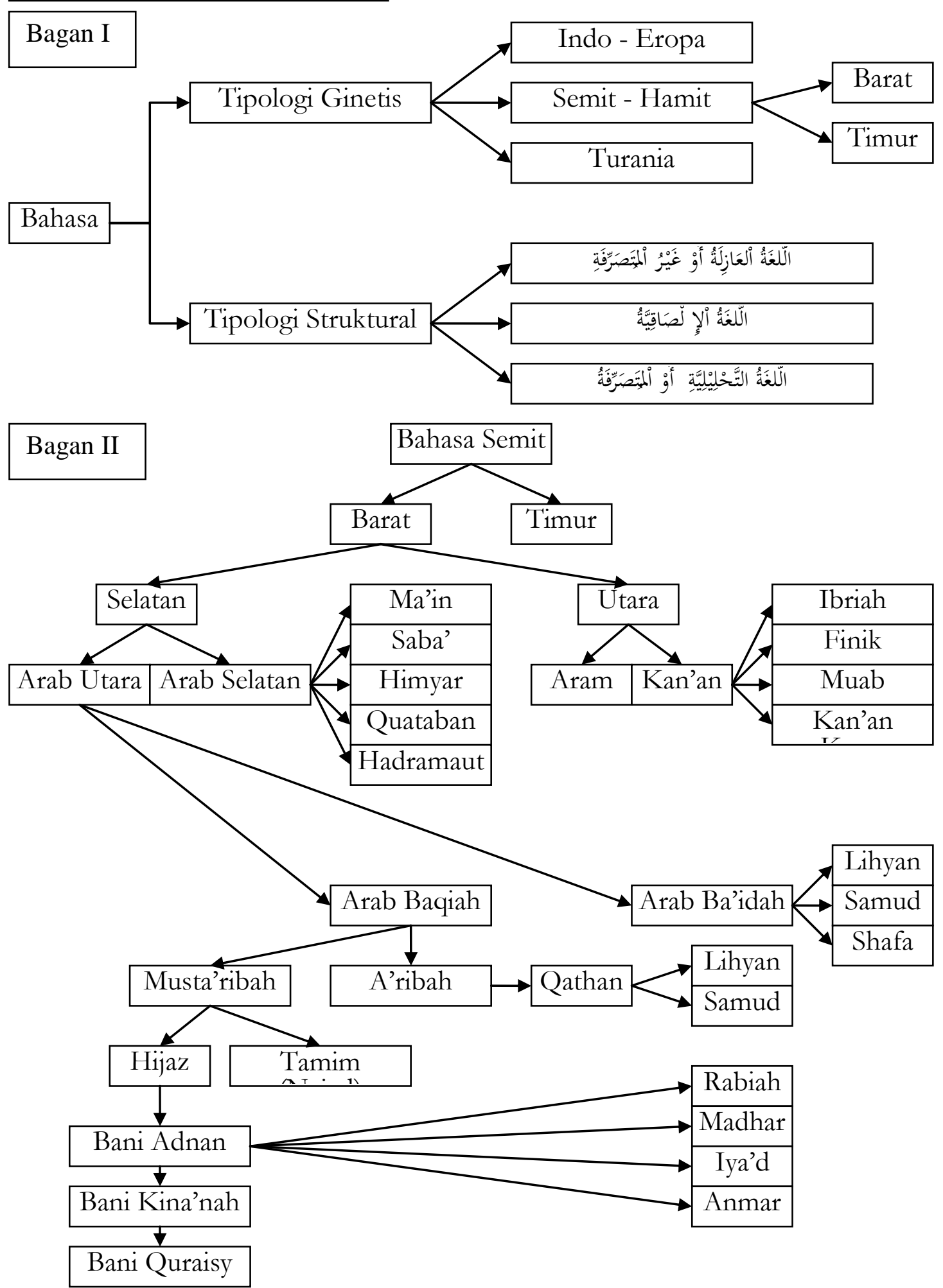


\section{E. Kesimpulan}

1. Bahasa Arab adalah salah satu bahasa yang termasuk rumpun bahasa-bahasa Semit yang berdiam di sebelah selatan, tepatnya di wilayah Irak. Bahasa Semit sebagai bahasa induk utama dalam bahasa Arab kemudian membentuk bahasa-bahasa lain setelah terpisah dari induknya. Bahasa Semit mulai terpecah-pecah seperti Babilonia, Assiriyah, Ibrani, Aramiyah, Arab dan Etopiah.

2. Bahasa Arab adalah temuan dari prasasti tentang Arab Baidah yang diperkirakan hidup pada abad pertama sebelum masehi, sedangkan Arab Baqiyah nanti setelah abad kelima masehi, sehingga priodisasi pertumbuhan bahasa Arab sangat sulit untuk dilacak. Perkembangan bahasa Arab meliputi perkembangannya di zaman sesudah datangnya islam, perkembangan bahasa Arab di zaman bani Umayyah, perkembangan bahasa Arab di zaman bani Abbasiah, perkembangan bahasa Arab sesudah abad V H. Dan perkembangan bahasa Arab di zaman modern.

3. Dalam pembagian bahasa Arab terbagi 2 (dua) kelompok besar yaitu; Arab Baidah dan Arab Baqiyah. Bahasa Arab Baidah ini dituturkan oleh orang Arab yang berdomisili di sebelah utara Hijaz atau berdekatan bangsa Aramiah. Bahasa Arab Baidah ini terbagi atas 3 (tiga) bagian; Lihyan, Samud, dan Shafa. Dan bahasa Arab Baqiyah terbagi atas dua bagian, yaitu bahasa Arab Aribah dan Musta'ribah.

4. Faktor-faktor yang membantu kemengan dialek Quraisy, antara lain; faktor agama, faktor ekonomi, faktor politik, faktor musyawarah dan faktor pasar. 


\section{DAFTAR PUSTAKA}

Ba'labaki, Ramzi Munir. Mu'jam al-Musthalahat al-Lugawiyyah, Bairut: Dar al-'Ilm li al- Malayin, 1990

Crystal., Linguistics, England, Middlessex, t.th.

Hafid, Abd. Karim, Berbagai Sudut Pandang dalam Memahami Bahasa Arab, Makassar : Alauddin University Press.2012.

Hafid, Abd. Karim, Kaidah - Kaidah Bahasa Arab dan Relevansinya dalam Memahami Ayat- Ayat al-Qur'an, Makassar : Alauddin University Press.2011.

Hermawan, Acep, MetodologiPembelajaran Bahasa Arab, Bandung: PT Remaja Rosdakarya, 2011

Inaniy, Mustafa., al- Wasîth Fî al-Adab al- 'Araby Wa Târikhuhu, Mesir: Dâr alMa'rif, t.th.

Karl, Brokleman., Târikh al- Adab al- 'Araby, Jilid I, Cet. IV; al- Qahirah: Dâr alMa'rif, t.th.

Al-Khu@li@, Muhammad 'Ali, Asa@li@b Tadri@s al-Lugah al-AArabiyyah, Riyadh: al-Mamlakah al-‘Arabiyyah al-Su’u@diyyah, 1982

Mulyanto Sumardi, et.al., Pedoman Pengajaran Bahasa Arab pada Perguruan Tinggi Agama Islam IAIN, Jakarta: Proyek Pengembangan Sistim Pendidikan RI, 1976

Nasution, Harun., Islam Ditinjau Dari Berbagai Aspeknya, Jilid I, Jakarta: Ui.-Press, 1985.

al- Shaleh, Subhi., Dirâsat fì Fikh al-Lughah, Cet II; Beirut: Mansyurat al- Maktabah al- Ahliyah, 1962.

Sudaryanto., Predikat-Obyek dalam Bahasa Indonesia, Jakarta: Djambatan, 1983.

Sumardi, Mulyanto, et.al., Pedoman Pengajaran Bahasa Arab pada Perguruan Tinggi Agama Islam IAIN, Jakarta: Proyek Pengembangan Sistim Pendidikan RI, 1976.

Suyuti Suhaib, Muhammad., Kajian Puisi Arab Pra Islam, Cet. I; Jakarta: al- Quswa, 1990.

Umam, Khatibul, et. al., Pedoman Pengajaran Bahasa Arab pada Perguruan Tinggi IAIN, Jakarta: Proyek Pengembangan Sistem Pendiikan Agama RI, 1975.

Wa'fi, Abdul Wahid., Ilmu al- lughah, Cet. V; Misr: Maktabah Nahdhah Misr, 1962.

Yudi, Bambang ., Kristal-kristal Ilmu Bahasa, Cet. I; Surabaya: Airlangga University Press, 1995.

Yayasan Kanisius., Teori Linguistik dan Bahasa Indonesia, Yogyakarta, t.p, 1980.

Zaidan, Tarikh Adab al-Lughah al-Arabiyyah, jilid 4, Cairo, MEsir: Dar al-Hilal, t.th 